\title{
Systematic Review \\ Delayed Effect of Dendritic Cells Vaccination on Survival in Glioblastoma: A Systematic Review and Meta-Analysis
}

\author{
Salvatore Cozzi ${ }^{1}$ D , Masoumeh Najafi ${ }^{2}$, Marzieh Gomar ${ }^{3}$, Patrizia Ciammella ${ }^{1}$, Cinzia Iotti ${ }^{1}$, Corrado Iaccarino ${ }^{4,5}$,
} Massimo Dominici ${ }^{6}$, Giacomo Pavesi ${ }^{4,5}$, Chiara Chiavelli ${ }^{7} \mathbb{D}$, Ali Kazemian ${ }^{3}$ and Amin Jahanbakhshi ${ }^{8, *}$ (D)

1 Radiation Therapy Unit, Azienda USL-IRCCS di Reggio Emilia, 42122 Reggio Emilia, Italy; Salvatore.Cozzi@ausl.re.it (S.C.); Patrizia.ciammella@ausl.re.it (P.C.); cinzia.iotti@ausl.re.it (C.I.)

2 Skull Base Research Center, Rasool Akram Hospital, Iran University of Medical Sciences, Tehran 14535, Iran; najafi.mas@iums.ac.ir

3 Radiation Oncology Research Center, Iran Cancer Institute, Tehran University of Medical Sciences, Tehran 1416753955, Iran; m.gomar1365@gmail.com (M.G.); Kazemian@tums.ac.ir (A.K.)

4 Department of Biomedical, Metabolic and Neural Sciences, University of Modena and Reggio Emilia, 41121 Modena, Italy; corrado.iaccarino@unimore.it (C.I.); giacomo.pavesi@unimore.it (G.P.)

5 Neurosurgery Division, University Hospital of Modena, 41125 Modena, Italy

6 Department of Medical and Surgical Sciences for Children \& Adults, Division of Oncology, University-Hospital of Modena and Reggio Emilia, 41121 Modena, Italy; massimo.dominici@unimore.it

7 Laboratory of Cellular Therapy, Department of Medical and Surgical Sciences for Children \& Adults, Division of Oncology, University of Modena and Reggio Emilia, 41121 Modena, Italy; chiara.chiavelli@unimore.it

8 Stem Cell and Regenerative Medicine Research Center, Iran University of Medical Sciences, Tehran 14535, Iran

* Correspondence: jahanbakhshi.a@iums.ac.ir; Tel.: +98-912-190-2231

check for

updates

Citation: Cozzi, S.; Najafi, M.; Gomar, M.; Ciammella, P.; Iotti, C.; Iaccarino,

C.; Dominici, M.; Pavesi, G.;

Chiavelli, C.; Kazemian, A.; et al. Delayed Effect of Dendritic Cells Vaccination on Survival in

Glioblastoma: A Systematic Review and Meta-Analysis. Curr. Oncol. 2022, 29, 881-891.

https://doi.org/10.3390/

curroncol29020075

Received: 6 December 2021

Accepted: 1 February 2022

Published: 4 February 2022

Publisher's Note: MDPI stays neutral with regard to jurisdictional claims in published maps and institutional affiliations.

Copyright: (C) 2022 by the authors. Licensee MDPI, Basel, Switzerland. This article is an open access article distributed under the terms and conditions of the Creative Commons Attribution (CC BY) license (https:// creativecommons.org/licenses/by/ $4.0 /)$.

\begin{abstract}
Background: Dendritic cell vaccination (DCV) strategies, thanks to a complex immune response, may flare tumor regression and improve patients' long-term survival. This meta-analysis aims to assess the efficacy of DCV for newly diagnosed glioblastoma patients in clinical trials. Methods: The study databases, including PubMed, Web of Knowledge, Google Scholar, Scopus, and Cochrane, were searched by two blinded investigators considering eligible studies based on the following keywords: "glioblastoma multiforme", "dendritic cell", "vaccination", "immunotherapy", "immune system", "immune response", "chemotherapy", "recurrence", and "temozolomide". Among the 157 screened, only 15 articles were eligible for the final analysis. Results: Regimens including DCV showed no effect on 6-month progression-free survival (PFS, HR = 1.385, 95\% CI: 0.822-2.335, $p=0.673$ ) or on 6 -month overall survival (OS, HR $=1.408,95 \% \mathrm{CI}: 0.882-2.248, p=0.754)$. In contrast, DCV led to significantly longer 1-year OS (HR = 1.936, 95\% CI: 1.396-2.85, $p=0.001$ ) and longer 2-year OS (HR $=3.670,95 \%$ CI: 2.291-5.879, $p=0.001$ ) versus control groups. Hence, introducing DCV could lead to increased 1 and 2-year survival of patients by 1.9 and 3.6 times, respectively. Conclusion: Antitumor regimens including DCV can effectively improve mid-term survival in patients suffering glioblastoma multiforme (GBM), but its impact emerges only after one year from vaccination. These data indicate the need for more time to achieve an anti-GBM immune response and suggest additional therapeutics, such as checkpoint inhibitors, to empower an earlier DCV action in patients affected by a very poor prognosis.
\end{abstract}

Keywords: glioblastoma; immunotherapy; dendritic cell vaccination; checkpoint inhibitor; survival

\section{Introduction}

Glioblastoma multiforme (GBM), the most common primary brain tumor, represents about half of the malignant glioma tumors in adults. The overall incidence of this tumor has been estimated to be 3.2 per hundred thousand populations with a median survival of 15 to 17 months [1]. The globally accepted therapeutic approach for GBM includes surgical resection, radiotherapy, and chemotherapy by temozolomide. However, its recurrence is very frequent, with a five-year survival rate of about $5 \%$ considering a maximal surgical 
resection and adjuvant therapies being achievable [2-4]. This progressive and invasive behavior necessitates the development of novel treatments [5].

Tumor cells, especially in brain tumors, can evade the immune cells via different mechanisms, such as antigenic modulation, lowering immunogenicity, and immune suppression $[6,7]$. Immunotherapy is progressively becoming an effective approach for activating the immune system to recognize and destroy tumor cells [8,9]. The application of immunotherapy for the treatment of different malignant tumors is discussed elsewhere, especially in metastatic settings [10-13]. However, immunotherapy in glioblastoma is much more challenging compared to other solid tumors because of its infiltrative nature and the complex structure of the blood-brain barrier in various parts of the tumor territory. Some clinical trials have been performed to assess the efficacy and safety of immunotherapy with different regimens. Overall, there are two main immunotherapy approaches: passive immunotherapy (with the aim to activate the immune system by monoclonal antibodies and immune checkpoint modulators to confer antitumor response), and active immunotherapy or vaccination (by presenting tumor antigens that stimulate the immune system to produce an endogenous anti-tumor response, leading to the long-term recognition and destruction of the tumor cells) [14]. In the latter type, viral vectors and dendritic cells (DC) have been applied as stimulators and modulators [15]. DCs act as coordinators of the innate immune response by releasing activating cytokines for cytotoxic lymphocytes and NK cells [16]. They present processed antigens to $\mathrm{B}$ and $\mathrm{T}$ lymphocyte subsets, leading to activation and memory induction [17].

Using dendritic cell vaccination (DCV) to induce tumor regression and improve patients' long-term survival has been demonstrated in several solid tumors [18]. Variability in DCV protocols includes different activation treatments, such as peptide, tumor antigen RNA, and whole tumor lysates, as well as combination therapy with immunomodulators [19]. Several studies have evaluated the treatment response to DCV in glioblastoma, but there are considerable inhomogeneities in the results. These variations in the results could be due to various methods in DCV preparations, concomitant treatments, or differences in patients' disease status. In this study, we analyzed the available clinical trials and focused on the time period in which the effect of DCV can become evident. We argue that a short life expectancy for glioblastoma may mask the effect of DCV. The results give us some explanation for such discrepancies in the outcomes of many clinical trials.

\section{Materials and Methods}

\subsection{Study Selection}

The present systematic review and meta-analysis followed the guidelines for the Preferred Reporting Items for Systematic Review and Meta-Analysis (PRISMA) revised in 2015 [20] and was generated by the following question: what is the clinical impact of DCV on GBM patient survival? Registration in PROSPERO, by the time of completion of the work, was not a routine local research protocol. Therefore, we do not have a registration number, although our search shows there is no similar registered study in PROSPERO. Databases including Medline, Web of Knowledge, Google Scholar, Scopus, and Cochrane were searched by two blinded investigators for all eligible studies based on the considered keywords, including "glioblastoma multiforme", "dendritic cell", "vaccination", "immunotherapy", "immune system", "immune response", "chemotherapy", "recurrence", and "temozolomide". The inclusion and exclusion criteria were as follows: (1) prospective clinical trials (in different phases I/II/III) evaluating survival in patients suffering from newly diagnosed GBM and scheduling for dendritic cell vaccination with and without temozolomide chemotherapy; (2) studies published in the English language; (3) studies with unclear or irreproducible results (i.e., lack of clear outcomes or presence of errors in methodology and/or analyses) were all excluded; (4) lack of access to the manuscript's full text was also considered an exclusion criterion, unless the abstracts had enough data for our analysis; (5) case reports, case series, and review papers were all excluded. As shown in the flow diagram of the study selection (Figure 1), 157 articles were initially 
collected by database searching. After removing 3 articles due to evidence of duplication, 154 records were primarily under-screened. Based on the mentioned criteria, 127 records were excluded, and the remaining 27 citations were assessed for further eligibility. Of those, 12 were also excluded due to the incompleteness of the data and contents. Finally, 15 articles were eligible for the final analysis [21-35] (Table 1).

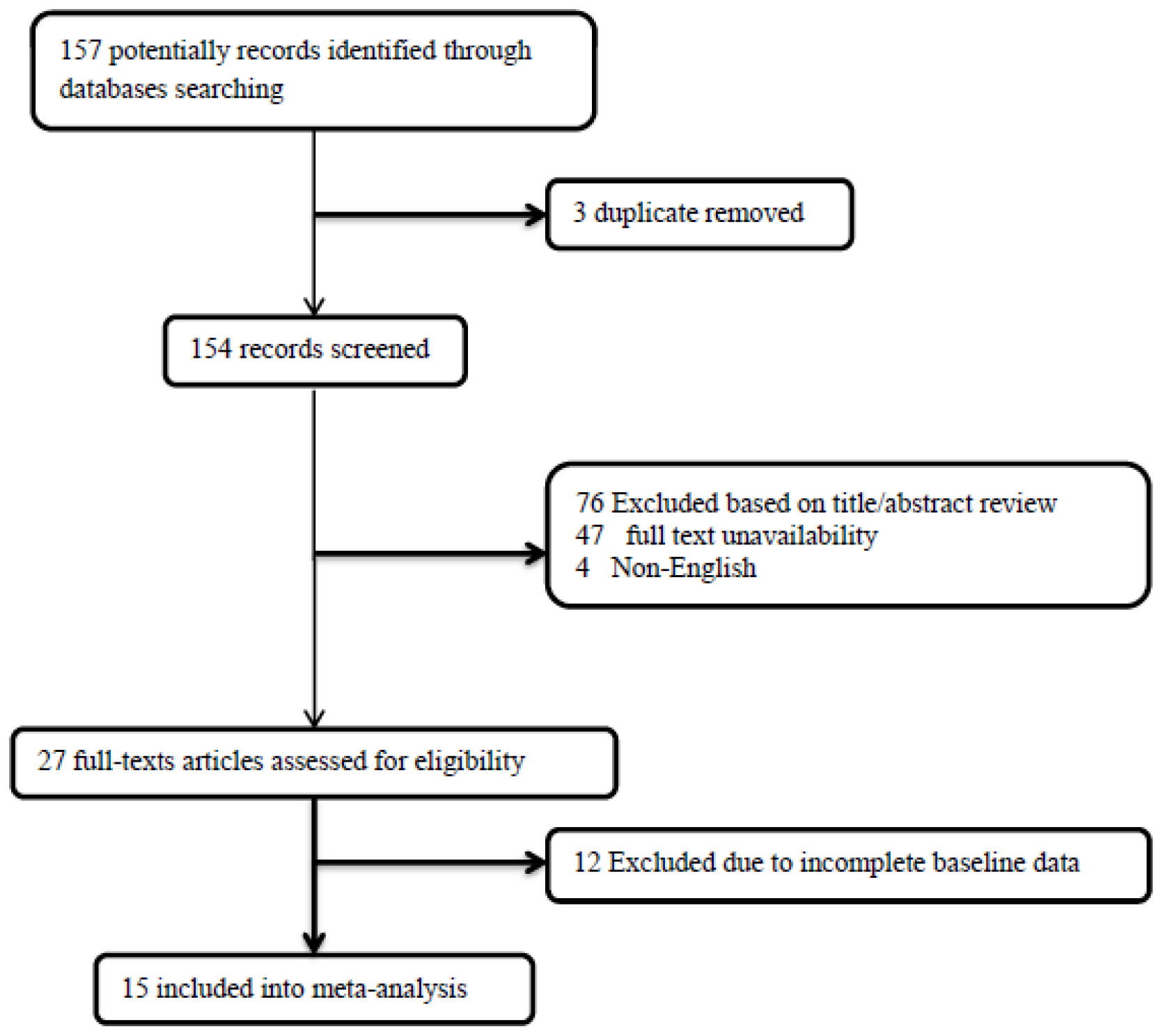

Figure 1. The flowchart of screening the eligible studies.

Table 1. Original data extracted from included studies.

\begin{tabular}{|c|c|c|c|c|c|c|c|c|}
\hline Author, Year & $\begin{array}{l}\text { Trial } \\
\text { Phase }\end{array}$ & $\begin{array}{l}\text { Type of } \\
\text { Tumor }\end{array}$ & Sample Size & $\begin{array}{l}\text { Mean } \\
\text { Age }\end{array}$ & $\begin{array}{l}\text { Male } \\
\text { Gender }\end{array}$ & $\begin{array}{l}\text { Follow-Up } \\
\text { (Months) }\end{array}$ & DCV Regimen & $\begin{array}{l}\text { Control } \\
\text { Group }\end{array}$ \\
\hline $\begin{array}{c}\text { Batich, } 2017 \\
\text { [21] }\end{array}$ & I & $\mathrm{ND}^{\mathrm{a}}$ & $\begin{array}{c}\text { Case: } 11 \\
\text { Control } \\
\text { (historical): } \\
23\end{array}$ & $\begin{array}{l}55 \\
55\end{array}$ & $\begin{array}{c}8 \\
16\end{array}$ & 60 & $\begin{array}{l}\text { pp65 lysosome-associated } \\
\text { membrane glycoprotein } \\
\text { mRNA-pulsed DCs }\end{array}$ & 60 \\
\hline
\end{tabular}


Table 1. Cont.

\begin{tabular}{|c|c|c|c|c|c|c|c|c|}
\hline Author, Year & $\begin{array}{c}\text { Trial } \\
\text { Phase }\end{array}$ & $\begin{array}{l}\text { Type of } \\
\text { Tumor }\end{array}$ & Sample Size & $\begin{array}{l}\text { Mean } \\
\text { Age }\end{array}$ & $\begin{array}{l}\text { Male } \\
\text { Gender }\end{array}$ & $\begin{array}{l}\text { Follow-Up } \\
\text { (Months) }\end{array}$ & DCV Regimen & $\begin{array}{l}\text { Control } \\
\text { Group }\end{array}$ \\
\hline $\begin{array}{l}\text { Buchroithner, } \\
2013 \text { [23] }\end{array}$ & II & ND & $\begin{array}{c}\text { Case: } 19 \\
\text { Control } \\
\text { (randomized): } \\
21\end{array}$ & $\mathrm{~N} / \mathrm{A}$ & $\mathrm{N} / \mathrm{A}$ & 18 & Not specified & 18 \\
\hline $\begin{array}{l}\text { Buchroithner, } \\
2018 \text { [22] }\end{array}$ & II & ND & $\begin{array}{c}\text { Case: } 34 \\
\text { Control } \\
\text { (randomized): } \\
\quad 42\end{array}$ & $\begin{array}{l}54.6 \\
54.0\end{array}$ & $\begin{array}{l}29 \\
22\end{array}$ & 12 & $\begin{array}{c}\text { Tumor lysate-charged } \\
\text { autologous DCs (Audencel) }\end{array}$ & 12 \\
\hline $\begin{array}{c}\text { Chang, } 2011 \\
{[24]}\end{array}$ & $\mathrm{I} / \mathrm{II}$ & ND & $\begin{array}{l}\text { Case: } 17 \\
\text { Control } \\
\text { (historical): } \\
\quad 63\end{array}$ & $\begin{array}{l}45 \\
42\end{array}$ & $\mathrm{~N} / \mathrm{A}$ & 60 & $\begin{array}{l}\text { Phagocytic DCs co-cultured } \\
\text { with autologous glioma } \\
\text { cells treated by IFN-gamma } \\
\text { and heat-shock treatment } \\
\text { and then irradiated with } \\
100 \mathrm{~Gy}\end{array}$ & 60 \\
\hline $\begin{array}{c}\text { Cho, } \\
2012[25]\end{array}$ & II & ND & $\begin{array}{c}\text { Case: } 18 \\
\text { Control } \\
\text { (randomized): } \\
16\end{array}$ & $\begin{array}{l}52.1 \\
55.8\end{array}$ & $\begin{array}{l}8 \\
8\end{array}$ & $\begin{array}{l}14-56 \\
17-53\end{array}$ & $\begin{array}{l}\text { Whole-tumor lysate pulsed } \\
\text { DCs }\end{array}$ & 14 \\
\hline Jie, 2012 [26] & II & ND & $\begin{array}{c}\text { Case: } 13 \\
\text { Control } \\
\text { (randomized): } \\
12\end{array}$ & $\begin{array}{l}40.2 \\
43.1\end{array}$ & $\begin{array}{c}10 \\
9\end{array}$ & 24 & $\begin{array}{c}\text { Autologous } \\
\text { glioblastoma-DCs } \\
\text { (GBM apoptosis induced by } \\
\text { heat-shock) }\end{array}$ & 22 \\
\hline $\begin{array}{l}\text { Leplina, } 2007 \\
\text { [27] }\end{array}$ & Pilot & ND & $\begin{array}{l}\text { Case: } 39 \\
\text { Control } \\
\text { (historical): } \\
80\end{array}$ & $\begin{array}{l}43 \\
46\end{array}$ & - & 36 & Interferon-induced DCs & 36 \\
\hline $\begin{array}{l}\text { Muller, } 2015 \\
\text { [28] }\end{array}$ & II & ND & $\begin{array}{l}\text { Case: } 117 \\
\text { Control } \\
\text { (historical): } \\
165\end{array}$ & $\begin{array}{l}51.0 \\
52.2\end{array}$ & - & 36 & Not specified & 30 \\
\hline $\begin{array}{c}\text { Prins, } 2011 \\
\text { [29] }\end{array}$ & I & ND & $\begin{array}{c}\text { Case: } 23 \\
\text { Control } \\
\text { (historical): } \\
68 \\
\end{array}$ & $\begin{array}{l}53 \\
55\end{array}$ & $\begin{array}{l}16 \\
48\end{array}$ & 60 & $\begin{array}{l}\text { Glioma lysate-pulsed DCs } \\
\text { booster vaccinations with } \\
\text { either imiquimod or } \\
\text { poly-ICLC adjuvant }\end{array}$ & 58 \\
\hline $\begin{array}{l}\text { Vik-Mo, } 2013 \\
\text { [30] }\end{array}$ & Pilot & ND & $\begin{array}{c}\text { Case: } 7 \\
\text { Control } \\
\text { (historical): } \\
10\end{array}$ & $\begin{array}{l}57 \\
62\end{array}$ & - & 24 & $\begin{array}{c}\text { Dendritic cell-based } \\
\text { vaccine targeting cancer } \\
\text { stem cells }\end{array}$ & 24 \\
\hline $\begin{array}{l}\text { Wheeler, } \\
2004 \text { [32] }\end{array}$ & $\mathrm{I} / \mathrm{II}$ & ND & $\begin{array}{c}\text { Case: } 25 \\
\text { Control } \\
\text { (randomized): } \\
13\end{array}$ & $\begin{array}{l}54 \\
56\end{array}$ & $\begin{array}{c}16 \\
4\end{array}$ & 48 & $\begin{array}{l}\text { Autologous DCs loaded } \\
\text { with HLA-eluted peptides } \\
\text { from cultured tumor cells } \\
\text { or autologous tumor } \\
\text { freeze-thaw lysate }\end{array}$ & 48 \\
\hline $\begin{array}{c}\text { Wen, } \\
2019 \text { [31] }\end{array}$ & II & ND & $\begin{array}{c}\text { Case: } 75 \\
\text { Control } \\
\text { (randomized): } \\
42\end{array}$ & $57.4,57.5$ & 44,31 & 40 & $\begin{array}{l}\text { DCs pulsed with six } \\
\text { synthetic peptide epitopes } \\
\text { targeting GBM tumor/stem } \\
\text { cell-associated antigens } \\
\text { MAGE-1, HER-2, AIM-2, } \\
\text { TRP-2, gP100, and IL13Ra2 }\end{array}$ & 39 \\
\hline $\begin{array}{c}\text { Yamanaka, } \\
2005 \text { [36] }\end{array}$ & $\mathrm{I} / \mathrm{II}$ & ND & $\begin{array}{l}\text { Case: } 18 \\
\text { Control } \\
\text { (historical): } \\
27\end{array}$ & $\begin{array}{l}50 \\
56\end{array}$ & - & 48 & $\begin{array}{l}\text { Peripheral blood DCs } \\
\text { pulsed with autologous } \\
\text { tumor lysate }\end{array}$ & 48 \\
\hline $\begin{array}{c}\text { Yao, } \\
2018 \text { [34] }\end{array}$ & II & ND & $\begin{array}{c}\text { Case: } 22 \\
\text { Control } \\
\text { (Randomized): } \\
21\end{array}$ & 48,50 & 13,11 & 14 & $\begin{array}{c}\text { DCs pulsed with } \\
\text { glioblastoma stem cell } \\
\text { lysates }\end{array}$ & 12 \\
\hline $\mathrm{Yu}, 2004$ [35] & I & ND & $\begin{array}{c}\text { Case: } 14 \\
\text { Control } \\
\text { (historical): } \\
26\end{array}$ & $\begin{array}{l}46 \\
53\end{array}$ & $\begin{array}{l}10 \\
18\end{array}$ & 60 & $\begin{array}{l}\text { Autologous DCs pulsed } \\
\text { with autologous tumor } \\
\text { lysate }\end{array}$ & 60 \\
\hline
\end{tabular}




\subsection{Data Extraction and Quality Assessment}

The data collection was independently performed by two unblinded reviewers on structured collection forms. We resolved disagreements by consensus or by involving a third person. The study quality was evaluated based on the following criteria: (1) the systematic review and meta-analysis based on the questions primarily described and formulated; (2) inclusion and exclusion criteria predefined in the studies as eligibility criteria; (3) searching the literature performed on a systematic and comprehensive approach; (4) to minimize the bias, the full texts of the article were dually reviewed; (5) the quality of the included studies was rated independently by the reviewers for appraising internal validity; (6) the studies' characteristics and findings were comprehensively listed; (7) the publication and risk of bias were listed; and (8) heterogeneity was also assessed. The nine-star Newcastle-Ottawa Scale (NOS) scoring system was employed to assess the methodological quality of all eligible studies. In this quality assessment technique, each study was assessed qualitatively for three criteria: the selection of the study groups, the comparability of the study groups, and the ascertainment of the outcome. The studies awarded 7 stars or more were deemed to be of high quality. Any disagreement was resolved by discussion in the whole study team. The endpoints of this meta-analysis are overall survival, progression-free survival, and toxicity associated with dendritic cell vaccination. Mid-term survival is considered outcomes encountered less than one year after treatment.

\subsection{Statistical Analyses}

The dichotomous variables are reported as proportions and percentages. The pooled likelihood of improving the survival of patients on different regimens was assessed and presented by the hazard ratio (HR) and $95 \%$ confidence interval (CI) as summary statistics. The fixed effects or random effects (in the case of significant heterogeneity across the data) models were used to obtained pooled dichotomous data using the mean difference (MD) followed by reporting 95\% CIs and its corresponding $p$ values. Cochrane's $Q$ test was used to determine the statistical heterogeneity. This test was complemented with the I2 statistic, which quantifies the proportion of total variation across studies that is due to heterogeneity rather than chance. Publication bias was assessed by the rank correlation test and also confirmed by funnel plot analysis. The reported values were two-tailed, and the hypothesis testing results were considered statistically significant at $p=0.05$. Statistical analysis was performed using the Comprehensive Meta-Analysis (CMA) software version 3.0 (Biostat, Englewood, NJ, USA).

\section{Results}

Study characteristics: In total, 15 clinical trials in the different phases ( 2 studies as first-in-man, 3 in phase I, 3 in phase I/II, and 7 in phase II), consisting of 452 cases and 629 controls, were included in our analysis. Regarding the GBM population included in the studies, all studies included only the cases with newly diagnosed GBM.

The quality assessment showed a NOS score of 7 or higher for all studies, indicating the presence of high methodological quality (Figure 2).

Efficacy outcomes: Among the 15 studies, 15 assessed the overall survival (OS) and progression-free survival (PFS), 12 determined the median OS time (months), 4 assessed the median PFS time (month), 6 assessed the mid-term PFS, and 12 assessed the mid-term OS. The OS and the PFS were significantly different between patients who received the $\mathrm{DCV}$ and those who did not. In this regard, using the DCV led to significantly longer OS (weighted mean differences of 5.775, 95\% CI: 3.901-7.649, $p<0.001$ ), and also longer PFS (weighted mean differences of 1.598, 95\% CI: 1.204-1.933, $p<0.014$ ). DCV could lead to increased OS and PFS by 5.7 and 1.5 times, respectively. The heterogeneity across the studies in OS and PFS measurements was significantly relevant, with $\mathrm{I}^{2}$ values of 91.564 to 92.325 , respectively. In terms of comparing the mid-term survival of patients receiving therapeutic regimens with and without considering $\mathrm{DCV}$, we observed no difference between the two groups 6-month PFS (HR $=1.385,95 \%$ CI: 0.822-2.335, $p=0.673$ ) and also 6-month 
OS (HR = 1.408, 95\% CI: 0.882-2.248, $p=0.754)$; however, DCV led to significantly longer 1 -year OS (HR = 1.936, 95\% CI: 1.396-2.85, $p=0.001)$ and longer 2-year OS (HR = 3.670, 95\% CI: 2.291-5.879, $p=0.001)$. Hence, introducing the DCV could lead to increased 1- and 2-year survival of patients by 1.9 and 3.6 times, respectively (Figure 3 ).

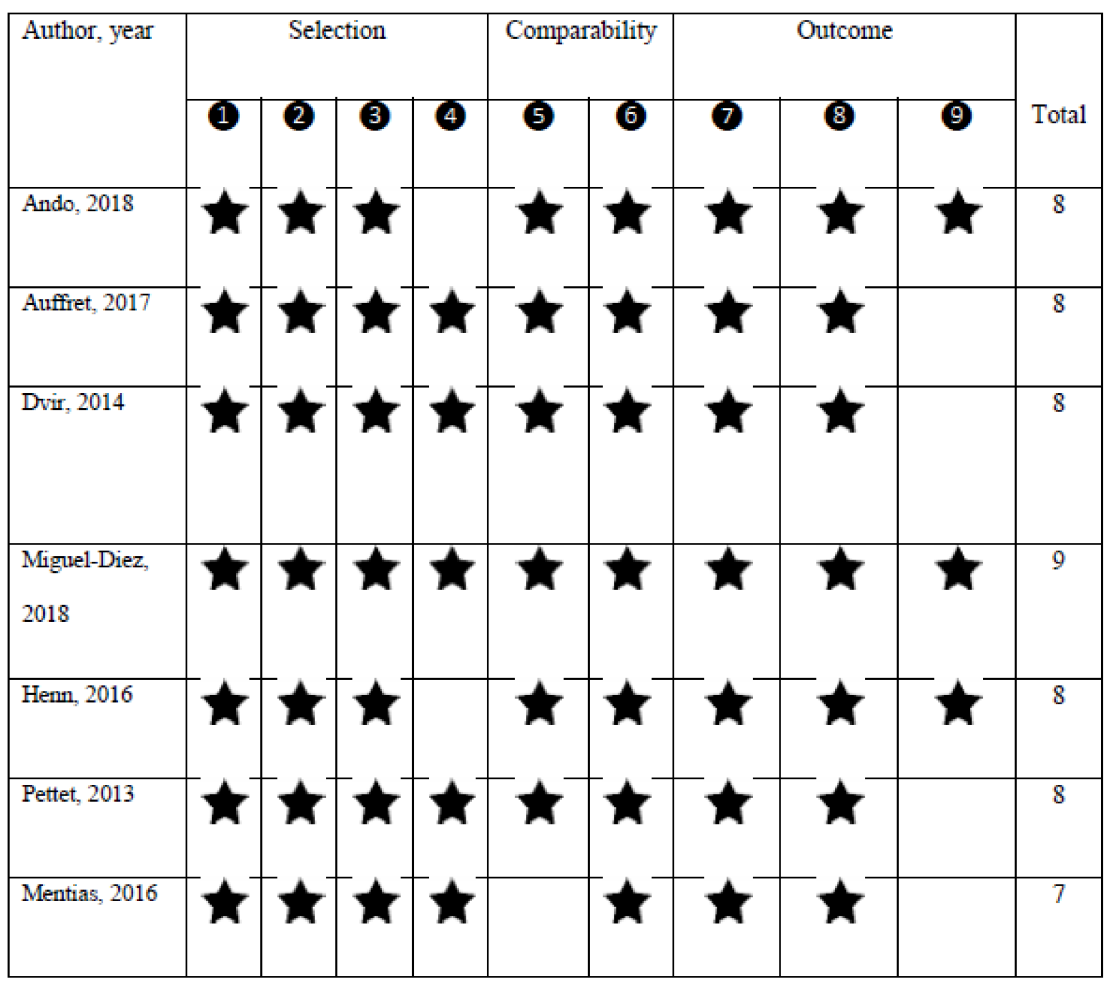

Figure 2. The quality assessment of the studies according to the nine-star Newcastle-Ottawa Scale (NOS) scoring system.

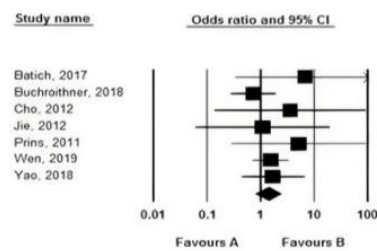

A

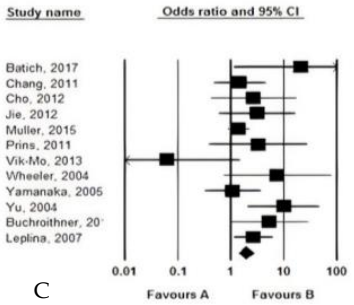

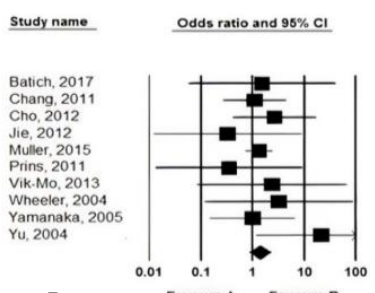

B

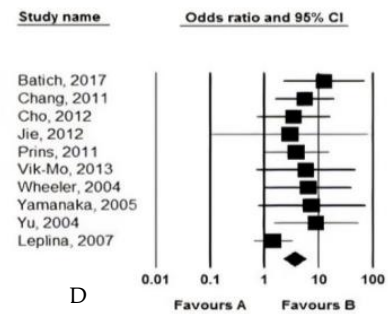

Figure 3. The pooled analysis of the efficacy of dendritic cell vaccination on mid-term survival (A: 6-month PFS, B: 6-month OS, C: 12-month OS, D: 24-month OS).

Safety outcomes: No side effects were reported following DCV protocols, and drugrelated complications were tolerable and reversible (Table 2). 
Table 2. The outcome of the dendritic cell vaccination strategy.

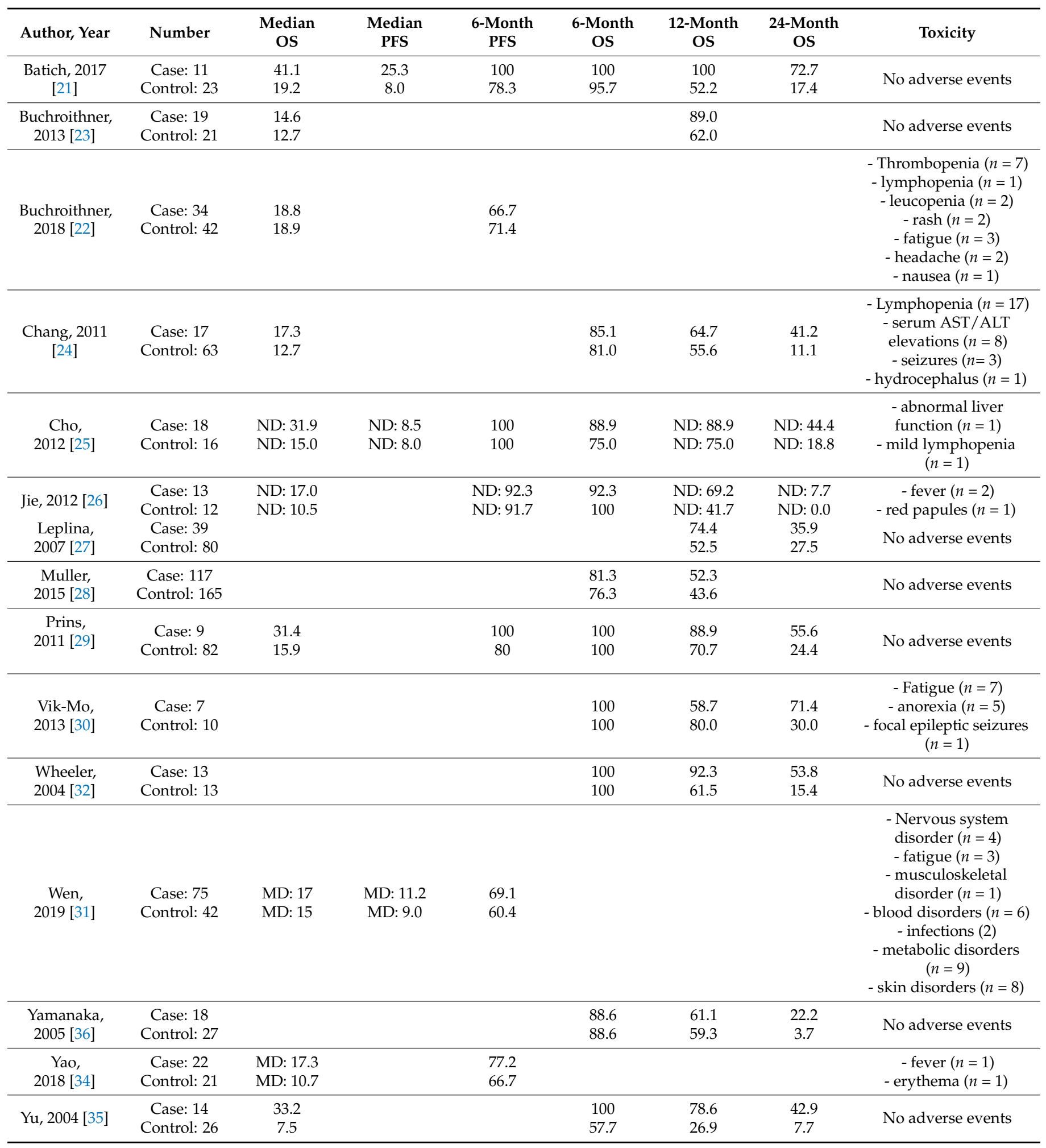

Publication bias: The heterogeneity across the studies in assessing the efficacy of DCV on mid-term survival was insignificant, with $\mathrm{I}^{2}$ values ranging from 0.0 to 0.39 , and Egger test excluded non-significant publication bias in the analyses.

\section{Discussion}

It can be inferred from many animal and human studies that the immune system can help shape the future of cancer treatment by recognizing malignant cells and destroying 
them efficiently. In fact, this tumor suppression role is mediated by both the cellular and humoral antitumor immune response, especially by $\mathrm{CD}^{+}$cytotoxic T lymphocytes [37]. Pathologically, $\mathrm{T}$ cells in cancer patients have been revealed to exhibit reactivity against tumor biochemical particles, including peptides and proteins derived from the tumor tissue that are sourced by occurring mutations on embryonic genes related to tumor growth and differentiation [38,39]. These potentials can provide new insights into developing therapeutic agents, such as creating vaccines for inhibiting cancer progression and improving patients' survival. Immunotherapy for GBM comprises various methods, including peptide and dendritic cell vaccines, checkpoint inhibitors, chimeric antigen receptor (CAR) T-cells, and oncolytic virotherapy [40]. Initially, vaccines originated from autologous tumor cells, tumor antigen peptides, or cell lysates generating promising immune responses [41]. However, by applying such methods, no specific immune antitumor response was achieved. In recent decades, one of the major discoveries in tumor immunotherapy has been to prove the critical role of specialized antigen-presenting cells, like the DC in the creation of cell-mediated immune responses by the production of cancer-specific vaccines [42]. The DCV against GBM has garnered special attention. Extensive clinical trials have been designed and conducted to prove its effectiveness and safety, but some have been met with conflicting results. In the present study, we aimed to summarize and interpret the results of these studies in order to reach a credible consensus. Hence, we systematically reviewed 15 clinical trials assessing the DCV efficacy on GBM patients' survival to ultimately reveal its significant efficacy in improving mid-term OS and OFS in patients with GBM. In other words, the introduction of DCV could effectively prolong patients' survival and, therefore, inhibit the tumor progression/recurrence. However, two important points are worth considering. The DCV treatment regimen is apparently incapable of generating a clinical measurable response in the short term, with no significant effect on patients' survival at 6 months. However, after a longer observation time (more than one year), the DCV shows its inhibitory effect on tumor progression.

In a meta-analysis performed by Vatu et al., the DCV resulted in improvements in OS and PFS (35\% and 41\%, respectively) and it was superior to viral therapy (four clinical trials on herpes simplex virus thymidine kinase/ganciclovir gene therapy were included) in both outcome measures. However, they did not analyze the results at different follow-up times. While there is only a $40 \%$ overlap in the final analyzed studies, our work includes $50 \%$ more patients in the case group [43]. Another meta-analysis performed by Artene et al. did not observe a significant improvement in OS and PFS by viral therapy, but they found a statistically significant improvement of OS by DCV in both primary and recurrent highgrade glioma. However, despite a trend toward an improvement in PFS, it did not reach a significant threshold. They analyzed 8 studies, including 104 patients in the experimental arm [44]. Cao et al. also found a significantly better outcome in terms of both OS and PFS after antigen-pulsed DC treatment at 1, 1.5, 2,3, and 4-year time points. Their study included nine clinical trials, six of which are also included in our study [45].

It can be hypothesized that the DCV would require more time to be effective against GBM, so that a more articulated immune response, including a combination of cellular and humoral immunity, could be established. Interestingly, Rangel-Reyes et al. have shown this delay in a mathematical model for dendritic cell treatment. They evaluated common obstacles, such as immunosuppression and poor transfer to lymph nodes, that reduce the effect of the DCV and entered them into a mathematical model, and showed that time can be considered in the model as the gestation time or transport delay of the DCV [46]. In addition, the DCV may have less effect on more invasive glioblastomas. Thus, its effect cannot be detected in a short time, during which these patients could die. In this particular setting, the potential to activate an immune response combining cell therapy with additional immuno-oncology tools, like checkpoint inhibitors (CPI), may generate a faster immune response. There are several clinical trials, such as NCT04201873 (using pembrolizumab) and NCT03014804 (using nivolumab), designed to investigate the efficacy of combined treatment with DCV and CPI. Moreover, one can find case presentations that 
report a good outcome for such a combination therapy [47]. However, more studies are needed to prove its safety and efficacy.

There are some limitations to the current study. The small number of clinical studies and patients enrolled in the meta-analysis, evaluation of newly diagnosed respectable GBM, differences in patients' characteristics between these studies, differences in DCV preparation protocols, and variations in concomitant administered therapeutics, may have affected the final analysis. It should be noted that, as shown in Table 1, many studies integrated into this meta-analysis are of a non-randomized or historical type. This may reduce the statistical significance of the analysis.

\section{Conclusions}

Among the different modalities for immunotherapy in glioblastoma, dendritic cell vaccination has gathered considerable attention after some encouraging reports that have shown acceptable levels of efficacy and safety. In the present review, we found that the effect of the DCV needs a minimum 6-month period to become significant-a finding that can be explained by mathematical models and pathophysiology. This vital outcome may explain some of the conflict between different clinical trials. We suggest a revision in the design of future clinical trials to include patients with longer expected survival periods, and also consider the incorporation of combination immunotherapies to boost the effect of the DCV. Nevertheless, the limitations of our work should be taken into account, including the limited number of studies and the fact that it may not be generalizable to recurrent glioblastoma and other high-grade gliomas.

Author Contributions: Conceptualization, A.J. and M.N.; methodology, M.G.; software, M.G.; validation, P.C., C.I. (Cinzia Iotti), and C.C.; formal analysis, M.G.; writing-original draft preparation, M.N. and A.J.; writing-review and editing, C.I. (Corrado Iaccarino), M.D. and G.P.; supervision, A.K.; project administration, S.C., M.N. and A.J. All authors have read and agreed to the published version of the manuscript.

Funding: This research received no external funding.

Conflicts of Interest: The authors declare no conflict of interest.

\section{References}

1. Schaller, T.H.; Sampson, J.H. Advances and Challenges: Dendritic Cell Vaccination Strategies for Glioblastoma. Expert Rev. Vaccines 2016, 16, 27-36. [CrossRef]

2. Golinelli, G.; Grisendi, G.; Prapa, M.; Bestagno, M.; Spano, C.; Rossignoli, F.; Bambi, F.; Sardi, I.; Cellini, M.; Horwitz, E.M.; et al. Targeting GD2-Positive Glioblastoma by Chimeric Antigen Receptor Empowered Mesenchymal Progenitors. Cancer Gene Ther. 2018, 27, 558-570. [CrossRef]

3. Schäfer, R.; Schwab, M.; Siegel, G.; von Ameln-Mayerhofer, A.; Buadze, M.; Lourhmati, A.; Wendel, H.-P.; Kluba, T.; Krueger, M.A.; Calaminus, C.; et al. Modulating Endothelial Adhesion and Migration Impacts Stem Cell Therapies Efficacy. eBiomedicine 2020, 60, 102987. [CrossRef]

4. Théry, C.; Witwer, K.W.; Aikawa, E.; Alcaraz, M.J.; Anderson, J.D.; Andriantsitohaina, R.; Antoniou, A.; Arab, T.; Archer, F.; Atkin-Smith, G.K.; et al. Minimal Information for Studies of Extracellular Vesicles 2018 (MISEV2018): A Position Statement of the International Society for Extracellular Vesicles and Update of the MISEV2014 Guidelines. J. Extracell. Vesicles 2018, 7, 1535750. [CrossRef]

5. Rossi, J.; Giaccherini, L.; Cavallieri, F.; Napoli, M.; Moratti, C.; Froio, E.; Serra, S.; Fraternali, A.; Ghadirpour, R.; Cozzi, S.; et al. Extracranial Metastases in Secondary Glioblastoma Multiforme: A Case Report. BMC Neurol. 2020, 20, 1-9. [CrossRef]

6. Beatty, G.L.; Gladney, W.L. Immune Escape Mechanisms as a Guide for Cancer Immunotherapy. Clin. Cancer Res. 2014, 21, 687-692. [CrossRef]

7. Stevenson, G.T. Three Major Uncertainties in the Antibody Therapy of Cancer. Haematologica 2014, 99, 1538-1546. [CrossRef] [PubMed]

8. Callahan, M.K. Immune Checkpoint Therapy in Melanoma. Cancer J. 2016, 22, 73-80. [CrossRef] [PubMed]

9. Topalian, S.L.; Taube, J.M.; Anders, R.A.; Pardoll, D.M. Mechanism-Driven Biomarkers to Guide Immune Checkpoint Blockade in Cancer Therapy. Nat. Cancer 2016, 16, 275-287. [CrossRef] [PubMed]

10. Galluzzi, L.; Chan, T.A.; Kroemer, G.; Wolchok, J.D.; López-Soto, A. The Hallmarks of Successful Anticancer Immunotherapy. Sci. Transl. Med. 2018, 10, eaat7807. [CrossRef] [PubMed] 
11. Li, X.; Wenes, M.; Romero, P.; Huang, S.C.-C.; Fendt, S.-M.; Ho, P.-C. Navigating Metabolic Pathways to Enhance Antitumour Immunity and Immunotherapy. Nat. Rev. Clin. Oncol. 2019, 16, 425-441. [CrossRef] [PubMed]

12. Pitt, J.M.; Marabelle, A.; Eggermont, A.; Soria, J.-C.; Kroemer, G.; Zitvogel, L. Targeting the Tumor Microenvironment: Removing Obstruction to Anticancer Immune Responses and Immunotherapy. Ann. Oncol. 2016, 27, 1482-1492. [CrossRef] [PubMed]

13. Trapani, J.A.; Darcy, P.K. Immunotherapy of Cancer. Aust. Fam. Physician 2017, 46, 194-199. [PubMed]

14. Reardon, D.A.; Freeman, G.; Wu, C.; Chiocca, E.A.; Wucherpfennig, K.W.; Wen, P.Y.; Fritsch, E.F.; Curry, W.T., Jr.; Sampson, J.H.; Dranoff, G. Immunotherapy Advances for Glioblastoma. Neuro-Oncology 2014, 16, 1441-1458. [CrossRef]

15. Mitchell, D.A.; Batich, K.A.; Gunn, M.D.; Huang, M.-N.; Sanchez-Perez, L.; Nair, S.K.; Congdon, K.L.; Reap, E.A.; Archer, G.E.; Desjardins, A.; et al. Tetanus Toxoid and CCL3 Improve Dendritic Cell Vaccines in Mice and Glioblastoma Patients. Nature 2015, 519, 366-369. [CrossRef] [PubMed]

16. Batich, K.; Swartz, A.M.; Sampson, J. Enhancing Dendritic Cell-Based Vaccination for Highly Aggressive Glioblastoma. Expert Opin. Biol. Ther. 2014, 15, 79-94. [CrossRef] [PubMed]

17. Wculek, S.K.; Cueto, F.J.; Mujal, A.M.; Melero, I.; Krummel, M.F.; Sancho, D. Dendritic Cells in Cancer Immunology and Immunotherapy. Nat. Rev. Immunol. 2020, 20, 7-24. [CrossRef]

18. Wylie, B.; Macri, C.; Mintern, J.; Waithman, J. Dendritic Cells and Cancer: From Biology to Therapeutic Intervention. Cancers 2019, 11, 521. [CrossRef]

19. Desai, R.; Suryadevara, C.M.; Batich, K.A.; Farber, S.H.; Sanchez-Perez, L.; Sampson, J.H. Emerging Immunotherapies for Glioblastoma. Expert Opin. Emerg. Drugs 2016, 21, 133-145. [CrossRef]

20. Shamseer, L.; Moher, D.; Clarke, M.; Ghersi, D.; Liberati, A.; Petticrew, M.; Shekelle, P.; Stewart, L.A.; The PRISMA-P Group. Preferred Reporting Items for Systematic Review and Meta-Analysis Protocols (PRISMA-P) 2015: Elaboration and Explanation. BMJ 2015, 349, g7647, Erratum in 2016, 354, i4086. [CrossRef]

21. Batich, K.A.; Reap, E.A.; Archer, G.E.; Sanchez-Perez, L.; Nair, S.K.; Schmittling, R.J.; Norberg, P.; Xie, W.; Herndon, J.E., II; Healy, P.; et al. Long-Term Survival in Glioblastoma with Cytomegalovirus pp65-Targeted Vaccination. Clin. Cancer Res. 2017, 23, 1898-1909. [CrossRef] [PubMed]

22. Buchroithner, J.; Erhart, F.; Pichler, J.; Widhalm, G.; Preusser, M.; Stockhammer, G.; Nowosielski, M.; Iglseder, S.; Freyschlag, C.F.; Oberndorfer, S.; et al. Audencel Immunotherapy Based on Dendritic Cells has no Effect on Overall and Progression-Free Survival in Newly Diagnosed Glioblastoma: A Phase II Randomized Trial. Cancers 2018, 10, 372. [CrossRef] [PubMed]

23. Buchroithner, J.; Pichler, J.; Marosi, C.; Widhalm, G.; Seiz-Rosenhagen, M.; Novosielski, M.; Oberndorfer, S.; Ruckser, R.; Roessler, K.; Azizi, A.; et al. Vascular Endothelia Growth Factor Targeted Therapy May Improve the Effect of Dendritic Cell-Based Cancer Immune Therapy. Int. J. Clin. Pharmacol. Ther. 2014, 52, 76-77. [CrossRef] [PubMed]

24. Chang, C.-N.; Huang, Y.-C.; Yang, D.-M.; Kikuta, K.; Wei, K.-J.; Kubota, T.; Yang, W.-K. A Phase I/II Clinical Trial Investigating the Adverse and Therapeutic Effects of a Postoperative Autologous Dendritic Cell Tumor Vaccine in Patients with Malignant Glioma. J. Clin. Neurosci. 2011, 18, 1048-1054. [CrossRef]

25. Cho, D.-Y.; Yang, W.-K.; Lee, H.-C.; Hsu, D.-M.; Lin, H.-L.; Lin, S.-Z.; Chen, C.-C.; Harn, H.-J.; Liu, C.-L.; Lee, W.-Y.; et al. Adjuvant Immunotherapy with Whole-Cell Lysate Dendritic Cells Vaccine for Glioblastoma Multiforme: A Phase II Clinical Trial. World Neurosurg. 2011, 77, 736-744. [CrossRef]

26. Jie, X.; Hua, L.; Jiang, W.; Feng, F.; Feng, G.; Hua, Z. Clinical Application of a Dendritic Cell Vaccine Raised against Heat-Shocked Glioblastoma. Cell Biophys. 2011, 62, 91-99. [CrossRef]

27. Leplina, O.Y.; Stupak, V.V.; Kozlov, Y.P.; Pendyurin, I.V.; Nikonov, S.D.; Tikhonova, M.; Sycheva, N.V.; Ostanin, A.A.; Chernykh, E. Use of Interferon- $\alpha$-Induced Dendritic Cells in the Therapy of Patients with Malignant Brain Gliomas. Bull. Exp. Biol. Med. 2007, 143, 528-534. [CrossRef] [PubMed]

28. Müller, K.; Henke, G.; Pietschmann, S.; Van Gool, S.; De Vleeschouwer, S.; Von Bueren, A.O.; Compter, I.; Friedrich, C.; Matuschek C.; Klautke, G.; et al. Re-Irradiation or Re-Operation Followed by Dendritic Cell Vaccination? Comparison of Two Different Salvage Strategies for Relapsed High-Grade Gliomas by Means of a New Prognostic Model. J. Neuro-Oncol. 2015, 124, 325-332. [CrossRef]

29. Prins, R.M.; Soto, H.; Konkankit, V.; Odesa, S.K.; Eskin, A.; Yong, W.H.; Nelson, S.F.; Liau, L. Gene Expression Profile Correlates with T-Cell Infiltration and Relative Survival in Glioblastoma Patients Vaccinated with Dendritic Cell Immunotherapy. Clin. Cancer Res. 2010, 17, 1603-1615. [CrossRef]

30. Vik-Mo, E.O.; Nyakas, M.; Mikkelsen, B.V.; Moe, M.C.; Due-Tønnesen, P.; Suso, E.M.I.; Sæbøe-Larssen, S.; Sandberg, C.; Brinchmann, J.E.; Helseth, E.; et al. Therapeutic Vaccination against Autologous Cancer Stem Cells with mRNA-Transfected Dendritic Cells in Patients with Glioblastoma. Cancer Immunol. Immunother. 2013, 62, 1499-1509. [CrossRef]

31. Wen, P.Y.; Reardon, D.A.; Armstrong, T.S.; Phuphanich, S.; Aiken, R.D.; Landolfi, J.C.; Curry, W.T.; Zhu, J.-J.; Glantz, M.; Peereboom, D.M.; et al. A Randomized Double-Blind Placebo-Controlled Phase II Trial of Dendritic Cell Vaccine ICT-107 in Newly Diagnosed Patients with Glioblastoma. Clin. Cancer Res. 2019, 25, 5799-5807. [CrossRef]

32. Wheeler, C.J.; Das, A.; Liu, G.; Yu, J.S.; Black, K.L. Clinical Responsiveness of Glioblastoma Multiforme to Chemotherapy after Vaccination. Clin. Cancer Res. 2004, 10, 5316-5326. [CrossRef] [PubMed]

33. Yamanaka, R.; Abe, T.; Yajima, N.; Tsuchiya, N.; Homma, J.; Kobayashi, T.; Narita, M.; Takahashi, M.; Tanaka, R. Vaccination of Recurrent Glioma Patients with Tumour Lysate-Pulsed Dendritic Cells Elicits Immune Responses: Results of a Clinical Phase I/II trial. Br. J. Cancer 2003, 89, 1172-1179. [CrossRef] [PubMed] 
34. Yao, Y.; Luo, F.; Tang, C.; Chen, D.; Qin, Z.; Hua, W.; Xu, M.; Zhong, P.; Yu, S.; Chen, D.; et al. Molecular Subgroups and B7-H4 Expression Levels Predict Responses to Dendritic Cell Vaccines in Glioblastoma: An Exploratory Randomized Phase II Clinical Trial. Cancer Immunol. Immunother. 2018, 67, 1777-1788. [CrossRef] [PubMed]

35. Yu, J.S.; Liu, G.; Ying, H.; Yong, W.H.; Black, K.L.; Wheeler, C.J. Vaccination with Tumor Lysate-Pulsed Dendritic Cells Elicits Antigen-Specific, Cytotoxic T-Cells in Patients with Malignant Glioma. Cancer Res. 2004, 64, 4973-4979. [CrossRef]

36. Yamanaka, R.; Homma, J.; Yajima, N.; Tsuchiya, N.; Sano, M.; Kobayashi, T.; Yoshida, S.; Abe, T.; Narita, M.; Takahashi, M.; et al. Clinical Evaluation of Dendritic Cell Vaccination for Patients with Recurrent Glioma: Results of a Clinical Phase I/II Trial. Clin. Cancer Res. 2005, 11, 4160-4167. [CrossRef] [PubMed]

37. Roth, C.; Rochlitz, C.; Kourilsky, P. Immune Response against Tumors. Curr. Protoc. Immunol. 1994, 57, 281-351. [CrossRef]

38. Jiang, W.; Swiggard, W.J.; Heufler, C.; Peng, M.; Mirza, A.; Steinman, R.M.; Nussenzweig, M.C. The Receptor DEC-205 Expressed by Dendritic Cells and Thymic Epithelial Cells Is Involved in Antigen Processing. Nature 1995, 375, 151-155. [CrossRef]

39. Tjoa, B.; Boynton, A.; Kenny, G.; Ragde, H.; Misrock, S.L.; Murphy, G. Presentation of Prostate Tumor Antigens by Dendritic Cells Stimulates T-Cell Proliferation and Cytotoxicity. Prostate 1996, 28, 65-69. [CrossRef]

40. Huang, B.; Li, X.; Li, Y.; Zhang, J.; Zong, Z.; Zhang, H. Current Immunotherapies for Glioblastoma Multiforme. Front. Immunol. 2021, 11, 3890. [CrossRef]

41. Adema, G.J.; Hartgers, F.; Verstraten, R.; De Vries, E.; Marland, G.; Menon, S.; Foster, J.; Xu, Y.; Nooyen, P.; McClanahan, T.; et al. A Dendritic-Cell-Derived C-C Chemokine that Preferentially Attracts Naive T Cells. Nature 1997, 387, 713-717. [CrossRef] [PubMed]

42. Qin, Z.; Noffz, G.; Mohaupt, M.; Blankenstein, T. Interleukin-10 Prevents Dendritic Cell Accumulation and Vaccination with Granulocyte-Macrophage Colony-Stimulating Factor Gene-Modified Tumor Cells. J. Immunol. 1997, 159, $770-776$.

43. Vatu, B.I.; Artene, S.-A.; Staicu, A.-G.; Turcu-Stiolica, A.; Folcuti, C.; Dragoi, A.; Cioc, C.; Baloi, S.-C.; Tataranu, L.G.; Silosi, C.; et al. Assessment of Efficacy of Dendritic Cell Therapy and Viral Therapy in High Grade Glioma Clinical Trials. A Meta-Analytic Review. J. Immunoass. Immunochem. 2018, 40, 70-80. [CrossRef] [PubMed]

44. Artene, S.-A.; Turcu-Stiolica, A.; Ciurea, M.E.; Folcuti, C.; Tataranu, L.G.; Alexandru, O.; Purcaru, O.S.; Tache, D.E.; Boldeanu, M.V.; Silosi, C.; et al. Comparative Effect of Immunotherapy and Standard Therapy in Patients with High Grade Glioma: A Meta-Analysis of Published Clinical Trials. Sci. Rep. 2018, 8, 11800. [CrossRef]

45. Cao, J.-X.; Zhang, X.-Y.; Liu, J.-L.; Li, D.; Li, J.-L.; Liu, Y.-S.; Wang, M.; Xu, B.-L.; Wang, H.-B.; Wang, Z.-X. Clinical Efficacy of Tumor Antigen-Pulsed DC Treatment for High-Grade Glioma Patients: Evidence from a Meta-Analysis. PLoS ONE 2014, 9, e107173. [CrossRef]

46. Rangel-Reyes, J.C.; Chimal-Eguia, J.C.; Castillo-Montiel, E. Dendritic Immunotherapy Improvement for an Optimal Control Murine Model. Comput. Math. Methods Med. 2017, 2017, 1-9. [CrossRef]

47. Pavelka, Z.; Zitterbart, K.; Nosková, H.; Bajčiová, V.; Slabý, O.; Štěrba, J. Effective Immunotherapy of Glioblastoma in an Adolescent with Constitutional Mismatch Repair-Deficiency Syndrome. Klin. Onkol. 2019, 32, 70-74. [CrossRef] [PubMed] 